\title{
KARAKTERISTIK KIMIAWI DARI DAGING KERANG TAHU, KERANG SALJU DAN KEONG MACAN
}

\author{
[Chemical Characteristics of Meretrix meretrix, Pholas dactylus \\ and Babylonia spirata Meat]
}

\author{
Asadatun Abdullah", ${ }^{1}$, Nurjanah ${ }^{1)}$, Taufik Hidayat ${ }^{2) \star}$, dan Rizky Chairunisah ${ }^{1)}$ \\ 1) Departemen Teknologi Hasil Perairan, Fakultas Perikanan dan Ilmu Kelautan, Institut Pertanian Bogor, Bogor \\ 2) Jurusan Perikanan, Fakultas Pertanian, Universitas Sultan Ageng Tirtayasa, Serang
}

Diterima 22 Maret 2017 / Disetujui 27 Juni 2017

\begin{abstract}
Meretrix meretrix, Pholas dactylus and Babylonia spirata are potential fisheries commodity, but information about their nutritional values is still limited. This research was aimed to determine the chemical compositions of Meretrix meretrix, Pholas dactylus and Bab ylonia spirata. Proximate of Meretrix meretrix, Pholas dactylus and Babylonia spirata were analyzed using thermogravimetric, soxhlet and kjeldahl methods. Their amino acid composition and taurine content were analyzed using High Performance Liquid Chromatografy (HPLC). The moisture, ash, fat, protein and carbohydrate contents of Meretrix meretrix were $79.98 \%, 1.370 .119 .39$ and 9.02 respectively; Pholas dactylus were $83.78 \%, 1.19,0.11,11.37$ and 3.55 respectively; while Babylonia spirata 78.44, 1.20, 0.33, 17.38 and 2.65 respectively. Arainine was the highest essential amino acid found in Meretrix meretrix, Pholas dactylus and Babylonia spirata meat with values of $1.12 \%, 0.93$ dan 2.50 respectively. Glutamic acid was the most abundant non-essential amino acid with the highest value of 2.24, 2.14 and 3.76. The limiting amino acid was histidine with the value of $0.25 \%, 0.18$ and 0.34 , respectively. The taurine content of Pholas dactylus meat $(0.085 \%)$ was higher than the Babylonia spirata and Meretrix meretrix (0.067 and $0.062 \%$, respectively).
\end{abstract}

Keywords: amino acids, Babylonia spirata, Meretrix meretrix, proximate, Pholas dactylus, taurine

\section{ABSTRAK}

Kerang tahu (Meretrix meretrix), kerang salju (Pholas dactylus) dan keong macan (Babylonia spirata) merupakan komoditi perikanan yang berpotensi untuk dikembangkan, namun informasi mengenai kandungan gizi kom oditi ters ebut sangat terbatas. Penelitian ini bertujuan menentukan komposisi kimiawi yang terdapat pada daging kerang tahu, kerang salju dan keong macan. Proksimat kerang tahu, kerang salju dan keong macan diuji dengan metode termogravimetri, soxhlet dan kjeldahl. Pengujian asam amino dan taurin diuji menggunakan metode High Performance Liquid Chromatography (HPLC). Kadar air, abu, lemak, protein dan karbohidrat kerang tahu berturut-turut adalah 79,$98 ; 1,37 ; 0,11 ; 9,39$ dan $9,02 \%$, kerang salju $83,78,1,19 ; 0,11 ; 11,37$ dan $3,55 \%$; keong macan 78,$44 ; 1,20 ; 0,33 ; 17,38$ dan $2,65 \%$. Kandungan asam amino esensial yang tertinggi daging kerang tahu, kerang salju dan keong macan adalah arginin sebesar 1,12;0,93 dan 2,50\%. Kandungan asam amino non esensial yang tertinggi adalah asam glutamat dengan nilai 2,$24 ; 2,14$ dan 3,76\%. Asam amino pembatas adalah histidin dengan nilai masing-masing adalah 0,25; 0,18 dan 0,34\%. Kandungan taurin pada daging kerang salju lebih besar yaitu $0,085 \%$ daripada keong macan dan kerang tahu sebesar yaitu 0,067 dan $0,062 \%$.

Kata kunci: asam amino, Babylonia spirata, Meretrix meretrix, proksimat, Pholas dactylus, taurin

\section{PENDAHULUAN}

Sektor perikanan sampai saat ini masih melakukan eksplorasi pada hasil laut yaitu tuna, udang dan rumput laut, sedangkan berbagai jenis moluska masih belum diminati untuk dikembangkan. Salah satu contoh moluska adalah kerang yang merupakan hasil perikanan dengan jumlah melimpah di

\footnotetext{
*Penulis Korespondensi:
}

E-mail: besthd22@gmail.com daerah tropis dan sumber protein hewani yang baik dan murah bagi masyarakat. Kerang berpotensi untuk dikembangkan menjadi salah satu produk ekspor yang dapat diandalkan. Menurut Nurjanah et al. (2014) Daging kerang merupakan makanan yang memiliki kandungan protein tinggi, nilai kalori rendah, rendah lemak atau rendah kolesterol dengan proporsi yang lebih rendah pada lemak jenuh, diet asam amino esensial, vitamin B12 dan mineral penting seperti zat besi, seng dan tembaga. 
Kerang salju (Pholas dactylus) merupakan komoditas yang belum banyak dikenal oleh masyarakat luas di Indonesia. Menurut Abdullah et al. (2016), pemanfaatannya di beberapa daerah hanya sebagai kerang konsumsi. Kerang tahu (Meretrix meretrix) di beberapa negara dijadikan sebagai indikator pencemaran logam berat dan untuk konsumsi. Keong macan (Babylonia spirata) merupakan salah satu komoditi ekspor Indonesia ke beberapa negara yaitu RRC, Taiwan, Hongkong, Malaysia dan Singapura. Produksi keong macan selama ini berasal dari hasil tangkapan di alam, diantaranya perairan Teluk Palabuhanratu. Penelitian mengenai bahan baku kerang salju, kerang tahu, dan keong macan yang sudah dilakukan yaitu profil asam lemak (Abdullah et al., 2016), sedangkan penelitian mengenai kekerangan yang mempunyai relevansinya terhadap perkembangan riset ini yaitu profil asam amino dan asam lemak kerang bulu (Abdullah et al., 2013), dan mengenai kandungan gizi kerang simping (Suptijah et al., 2013). Beberapa penelitian yang telah dilakukan menjadikan dasar untuk mencari kandungan gizi yang terkandung pada kerang jenis Bivalvia. Salah satu komposisi gizi yang penting serta banyak terdapat paa kerang (moluska) adalah taurin. Keunggulan khas dari jenis kekerangan adalah zat gizi taurin yang sangat bermanfaat bagi kesehatan. Jepang telah memanfaatkan taurin sebagai minuman yang dapat menambah stamina dalam tubuh.

Kandungan taurin pada setiap moluska berbeda-beda. Taurin berbeda dengan asam amino karena tidak memiliki gugus karboksilat. Taurin di dalam tubuh manusia banyak dijumpai pada hati, ginjal, otot, jantung, limpa, testis, otak dan banyak ditemukan dalam jumlah terbesar pada otot jantung. Otot mengandung $75 \%$ dari taurin pada tubuh manusia. Manfaat taurin adalah untuk mencegah diabetes, mencegah kerusakan liver akibat alkohol, penyembuhan pada masalah penglihatan, menurunkan kadar kolesterol darah, menormalkan tekanan darah dan melawan penyakit hati (Okuzumi dan Fujii, 2000). Taurin juga sangat dibutuhkan pada saat perkembangan dan pertumbuhan, oleh sebab itu dapat ditemukan pada hampir semua susu-susu formula untuk bayi dan suplemen memiliki kandungan taurin. Sebagian besar konsumen taurin di Indonesia adalah umat Islam yang mempunyai aturan tertentu terhadap makanan yang bersumber pada hewan, hal inilah yang menyebabkan perlu dicarinya sumber taurin yang halal sebagai alternatif untuk susu formula dan suplemen anak.

Mengingat asam amino dan taurin penting bagi tubuh manusia, maka perlu adanya penelitian mengenai jenis dan jumlah asam amino kerang tahu, kerang salju dan keong macan. Semakin lengkap informasi mengenai kandungan gizi kerang tahu, kerang salju dan keong macan maka diharapkan dapat membantu masyarakat untuk meningkatkan pemanfaatan yang lebih optimal dari komoditi tersebut. Penelitian ini bertujuan menentukan jenis dan jumlah asam amino serta taurin yang terdapat pada daging kerang tahu, kerang salju dan keong macan.

\section{BAHAN DAN METODE}

\section{Bahan}

Bahan utama yang digunakan dalam penelitian ini adalah kerang tahu (Meretrix meretrix), kerang salju (Pholas dactylus) dan keong macan (Babylonia spirata) yang didapatkan dari Muara Angke Jakarta.

\section{Metode penelitian}

Penelitian ini diawali dengan pengambilan sampel dari Muara Angke, Jakarta. Pengambilan sampel dibantu oleh para nelayan-nelayan di muara angke dengan kondisi segar. Rata-rata ketiga bobot kerang tersebut berkisar 29-75 gram dengan tiap sampel 30 ekor. Daging-daging dari kerang tahu, kerang salju dan keong macan dipisahkan dari cangkangnya, setelah itu dilakukan perhitungan rendemen dan analisis proksimat meliputi kadar air, abu, protein, lemak, dan karbohidrat. Analisis asam amino dan taurin menggunakan High Performance Liquid Chromatography (HPLC) (Shimadzu, Japan) terdiri dari empat tahap, yaitu: tahap pembuatan hidrolisat protein, pengeringan, derivatisasi dan injeksi serta analisis asam amino (Abdullah et al., 2013). Metode analisis asam amino memiliki prinsip mengubah protein menjadi asam amino sehingga dapat terdeteksi oleh kromatogram. Hasil analisis akan terekam dalam suatu lembaran yang terhubung dengan perekam dan ditunjukkan melalui beberapa puncak dengan waktu retensi tertentu sesuai dengan karakter masing-masing asam amino.

\section{Analisis kadar air (AOAC, 2007)}

Pengeringan cawan porselen dalam oven pada suhu $105^{\circ} \mathrm{C}$ selama 1 jam. Cawan tersebut diletakkan ke dalam desikator kemudian ditimbang. Sampel sebanyak $5 \mathrm{~g}$ dimasukkan ke dalam cawan tersebut, kemudian dikeringkan dengan oven pada suhu $105^{\circ} \mathrm{C}$ selama 5 jam atau hingga beratnya konstan. Cawan tersebut kemudian dimasukkan ke dalam desikator dan ditimbang kembali. Persentase kadar air (berat basah) dapat dihitung dengan rumus sebagai berikut:

$$
\text { Kadar Air }(\%)=\frac{A-B}{A} \times 100 \%
$$

Keterangan:

$A=$ berat sampel sebelum dikeringkan

$\mathrm{B}=$ berat sampel setelah dikeringkan 


\section{Analisis kadar abu (AOAC, 2007)}

Cawan pengabuan dikeringkan di dalam oven selama 1 jam pada suhu $105^{\circ} \mathrm{C}$, kemudian dimasukkan selama 15 menit di dalam desikator dan ditimbang hingga didapatkan berat yang konstan. Sampel sebanyak $5 \mathrm{~g}$ dimasukkan ke dalam cawan pengabuan dan dipijarkan di atas nyala api hingga tidak berasap lagi. Sampel dimasukkan ke dalam tanur pengabuan dengan suhu $600^{\circ} \mathrm{C}$ selama 7 jam, kemudian ditimbang hingga didapatkan berat yang konstan. Kadar abu dapat dihitung dengan rumus berikut:

Kadar Abu (\%) =

$\frac{\text { berat sampel dan cawan setelah di tanur-berat cawan kosong }}{\text { berat sampel awal }} \times 100 \%$

\section{Analisis kadar lemak (AOAC, 2007)}

Sampel seberat $5 \mathrm{~g}$ dimasukkan ke dalam kertas saring pada kedua ujung bungkus ditutup dengan kapas bebas lemak dan selanjutnya dimasukkan ke dalam selongsong lemak, kemudian sampel yang telah dibungkus dimasukkan ke dalam labu lemak yang sudah ditimbang dan disambungkan dengan tabung Soxhlet. Selongsong lemak dimasukkan ke dalam ruang ekstraktor tabung Soxhlet dan disiram dengan pelarut lemak ( $\mathrm{n}$ heksana) (Merck, Germany), kemudian dilakukan refluks selama 6 jam. Pelarut lemak yang ada dalam labu lemak didestilasi hingga semua pelarut lemak menguap. Pelarut akan tertampung di ruang ekstraktor pada saat destilasi, kemudian pelarut dikeluarkan sehingga tidak kembali ke dalam labu lemak. Labu lemak dikeringkan dalam oven pada suhu $105^{\circ} \mathrm{C}$, setelah itu labu dimasukkan dalam desikator sampai beratnya konstan. Kadar lemak dapat dihitung berdasarkan rumus:

$$
\operatorname{Kadar} \operatorname{Lemak}(\%)=\frac{\mathrm{W}_{3}-\mathrm{W}_{2}}{\mathrm{~W}_{1}} \times 100 \%
$$

Keterangan:

$\mathrm{W}_{1}=$ Berat sampel $(\mathrm{g})$

$\mathrm{W}_{2}=$ Berat labu lemak tanpa lemak $(\mathrm{g})$

$\mathrm{W}_{3}=$ Berat labu lemak dengan lemak $(\mathrm{g})$

\section{Analisis kadar protein (AOAC, 2007)}

Tahapan yang dilakukan dalam analisis protein terdiri dari tiga tahap, yaitu destruksi, destilasi, dan titrasi. Sampel sebanyak 0,4 g dimasukkan ke dalam tabung Kjeldahl, kemudian ditambahkan 0,4 $\mathrm{g}$ selenium (Merck, Germany) dan $10 \mathrm{~mL} \mathrm{H}_{2} \mathrm{SO}_{4}$ pekat (Merck, Germany). Tabung yang berisi larutan tersebut dimasukkan ke dalam alat destruksi selama 1 jam pada suhu $400^{\circ} \mathrm{C}$. Proses destruksi dilakukan sampai larutan berwarna hijau jernih. Larutan hasil destruksi diencerkan dengan akuades hingga 100 $\mathrm{mL}$ dalam labu takar. Larutan sampel hasil destruksi dipipet sebanyak $10 \mathrm{~mL}$ lalu dimasukkan ke dalam alat destilasi dan ditambahkan $10 \mathrm{~mL} \mathrm{NaOH} 40 \%$ (Merck, Germany). Cairan dalam ujung tabung kondensor ditampung dalam erlenmeyer $50 \mathrm{~mL}$ berisi larutan $\mathrm{H}_{3} \mathrm{BO}_{3}$ (Merck, Germany) dan 2 tetes indikator (cairan methyl red dan bromo cresol green) (Merck, Germany) yang ada di bawah kondensor. Destilasi dilakukan sampai diperoleh larutan berwarna hijau kebiruan. Titrasi dilakukan dengan menggunakan $\mathrm{HCl} 0,1 \mathrm{~N}$ (Merck, Germany) sampai warna larutan dalam erlenmeyer berubah menjadi merah muda. Volume titran dibaca dan dicatat. Kadar protein ditentukan dengan rumus berikut:

$\% \mathrm{~N}=$

$\underline{\text { ( } \mathrm{mL} \mathrm{HCl} \mathrm{sampel-mL} \mathrm{HCl} \mathrm{blanko)} \times \mathrm{N} \mathrm{HCl} \times \text { faktor pengenceran } \times 14,007} \times 100 \%$ mg sampel

Kadar Protein $(\%)=\% \mathrm{~N} \times$ faktor konversi

Keterangan:

Faktor pengenceran $=10 ;$ Faktor konversi $=6,25$

\section{Analisis kadar karbohidrat (by difference)}

Tujuan analisis karbohidrat, yaitu untuk mengetahui kandungan karbohidrat pada suatu bahan. Kadar karbohidrat ditentukan dengan rumus berikut:

Kadar Karbohidrat $(\%)=100 \%-(A+B+C+D)$

Keterangan:

$\mathrm{A}=$ Kadar air

$\mathrm{C}=$ Kadar protein

$\mathrm{B}=$ Kadar lemak

$\mathrm{D}=$ Kadar $\mathrm{abu}$

\section{Pembuatan hidrolisat protein (Abdullah et al.,} 2013)

Sampel ditimbang sebanyak $0,1 \mathrm{~g}$ dan dihancurkan. Sampel yang telah hancur ditambahkan $\mathrm{HCl} 6$ $\mathrm{N}$ sebanyak $10 \mathrm{~mL}$ yang kemudian dipanaskan dalam oven pada suhu $100^{\circ} \mathrm{C}$ selama 24 jam. Pemanasan dilakukan untuk mempercepat reaksi hidrolisis.

\section{Pengeringan sampel (Abdullah et al., 2013)}

Penyaringan bertujuan agar larutan yang dihasilkan benar-benar bersih, terpisah dari padatan. Hasil saringan diambil sebanyak $30 \mu \mathrm{L}$ dan ditambahkan dengan $30 \mu \mathrm{L}$ larutan pengering. Larutan pengering dibuat dari campuran natrium karbonat (Merck, Germany), pereaksi carrez (Merck, Germany), larutan danzil klorida dan metilamin hidroklorida (Merck, Germany) dengan perbandingan 4:4:3.

\section{Derivatisasi (Abdullah et al., 2013)}

Larutan derivatisasi sebanyak $30 \mu \mathrm{L}$ ditambahkan pada hasil pengeringan, larutan derivatisasi dibuat dari campuran methanol (Merck, Germany), 
natrium asetat (Merck, Germany) dan trietilamin (Merck, Germany) dengan perbandingan 3:3:4. Proses derivatisasi dilakukan agar detektor mudah untuk mendeteksi senyawa yang ada pada sampel, selanjutnya dilakukan pengenceran dengan cara menambahkan $20 \mathrm{~mL}$ asetonitril 60\% (Sigma, UK) atau buffer natrium asetat $1 \mathrm{M}$, Ialu dibiarkan selama 20 menit.

\section{Injeksi ke HPLC (Abdullah et al., 2013)}

Hasil saringan diambil sebanyak $40 \mu \mathrm{L}$ untuk diinjeksikan ke dalam HPLC. Perhitungan konsentrasi asam amino yang ada pada bahan dilakukan dengan pembuatan kromatogram standar dengan menggunakan asam amino yang telah siap pakai yang mengalami perlakuan yang sama dengan sampel. Kadar asam amino dalam bahan dapat dihitung dengan rumus berikut:

Asam Amino $(\%)=$ $\frac{\text { luas area sampel } \times \text { C } \times \text { Fp } \times \text { BM }}{\text { luas area standar } \times \text { bobot sampel }} \times 100 \%$

Keterangan:

C $=$ Konsentrasi standar asam amino $(\mu \mathrm{g} / \mathrm{mL})$

$\mathrm{Fp}=$ Faktor pengenceran

$\mathrm{BM}=$ Bobot molekul dari masing-masing asam amino $(\mathrm{g} / \mathrm{mol})$

\section{Analisis taurin (AOAC, 2007)}

Kandungan taurin dapat dianalisis menggunakan alat HPLC. Pengujian kadar taurin, sampel ditimbang sebanyak $0,5 \mathrm{~g}$ dan dimasukkan ke dalam tabung ukur $100 \mathrm{~mL}$, kemudian ditambahkan $80 \mathrm{~mL}$ air suling dan $1 \mathrm{~mL}$ pereaksi carrez lalu dikocok hingga homogen. Selanjutnya dilakukan pengenceran dengan cara menambahkan air suling sampai tanda tera dan dikocok hingga homogen. Tahap selanjutnya, larutan disaring menggunakan kertas saring whatman. Filtrat ditampung dalam erlenmeyer dan disimpan di tempat yang gelap. Selanjutnya dilakukan tahap derivatisasi dengan mengambil 1 $\mathrm{mL}$ ekstrak sampel dimasukkan ke labu takar $10 \mathrm{~mL}$, kemudian ditambahkan $1 \mathrm{~mL}$ buffer natrium karbonat dan $1 \mathrm{~mL}$ larutan dansil klorida. Setelah itu sampel didiamkan selama 2 jam lalu dikocok dan ditambahkan $0,5 \mathrm{~mL}$ laturan metilamin hidroklorida kemudian dikocok kembali hingga homogen. Hasil derivatisasi diambil sebanyak $40 \mu \mathrm{L}$ kemudian diinjeksikan ke dalam HPLC untuk mengetahui kandungan taurin pada sampel.

\section{Data analisis}

Analisis data dilakukan dengan statistik deskriptif dengan menggunakan software Microsoft Excel.

\section{HASIL DAN PEMBAHASAN}

\section{Karakteristik kerang tahu, kerang salju dan keong macan}

Kerang tahu, kerang salju dan keong macan yang digunakan pada penelitian ini memiliki ukuran dan bobot yang berbeda-beda yang dapat dilihat pada Tabel 1 . Kerang tahu memiliki panjang ratarata $4,26 \mathrm{~cm}$, lebar rata-rata $3,60 \mathrm{~cm}$, tinggi rata-rata $1,87 \mathrm{~cm}$ dan bobot total rata-rata sebesar $20,9 \mathrm{~g}$. Kerang salju memiliki panjang rata-rata $10,58 \mathrm{~cm}$, lebar rata-rata $3,32 \mathrm{~cm}$, tinggi rata-rata $3,04 \mathrm{~cm}$ dan bobot total rata-rata sebesar $58,1 \mathrm{~g}$. Keong macan memiliki panjang rata-rata $4,16 \mathrm{~cm}$, lebar rata-rata $2,87 \mathrm{~cm}$, tinggi rata-rata $1,94 \mathrm{~cm}$ dan bobot total rata-rata sebesar $16,6 \mathrm{~g}$. Perbedaan ukuran dan berat kerang dipengaruhi oleh pertumbuhan. Pertumbuhan adalah perubahan ukuran, baik berat, panjang maupun volume dalam laju perubahan waktu. Pertumbuhan dipengaruhi oleh beberapa faktor yaitu faktor dalam dan luar. Faktor dalam merupakan faktor yang sukar untuk dikontrol, contohnya keturunan. Sedangkan faktor luar merupakan faktor yang dapat dikontrol, diantaranya adalah makanan dan suhu (Nurjanah et al., 2015).

Tabel 1. Ukuran dan bobot kerang tahu, kerang salju dan keong macan

\begin{tabular}{lccc}
\hline \multicolumn{1}{c}{ Parameter } & $\begin{array}{c}\text { Kerang } \\
\text { Tahu }\end{array}$ & $\begin{array}{c}\text { Kerang } \\
\text { Salju }\end{array}$ & $\begin{array}{c}\text { Keong } \\
\text { Macan }\end{array}$ \\
\hline Panjang $(\mathrm{cm})$ & $4,26 \pm 0,27$ & $10,58 \pm 0,85$ & $4,16 \pm 0,27$ \\
Lebar $(\mathrm{cm})$ & $3,60 \pm 0,31$ & $3,32 \pm 0,27$ & $2,87 \pm 0,17$ \\
Tinggi $(\mathrm{cm})$ & $1,87 \pm 0,17$ & $3,04 \pm 0,34$ & $1,94 \pm 0,19$ \\
Bobot total $(\mathrm{g})$ & $20,9 \pm 4,21$ & $58,1 \pm 11,51$ & $16,6 \pm 2,43$ \\
\hline
\end{tabular}

Rendemen merupakan suatu parameter yang paling penting untuk mengetahui nilai ekonomis dan efektivitas suatu produk atau bahan. Rendemen yang dapat diperoleh dari ketiga sampel berupa cangkang, daging dan jeroan yang dapat dilhat pada Tabel 2. Kerang tahu segar memiliki nilai rendemen tertinggi pada cangkang yaitu sebesar $67,44 \%$, rendemen daging sebesar $14,38 \%$ dan rendemen jeroan sebesar $18,18 \%$. Kerang salju segar memiliki nilai rendemen tertinggi pada cangkang yaitu sebesar $60,64 \%$, rendemen daging sebesar $15,48 \%$ dan rendemen jeroan sebesar $23,88 \%$. Keong macan segar memiliki nilai rendemen tertinggi pada cangkang yaitu sebesar $67,03 \%$, rendemen daging sebesar $21,81 \%$ dan rendemen jeroan sebesar $11,16 \%$. Tingginya nilai rendemen cangkang menunjukkan nilai efisiensi dari suatu proses produksi untuk menghasilkan sejumlah produk akhir. Menurut Okuzumi dan Fujii (2000), ada beberapa peneliti yang membuat tepung dari limbah cangkang karena cangkang mengandung mineral penting yaitu kalsium dan fosfor. Jenis-jenis kekerangan, udang, oyster, cumi-cumi insekta dan fungi merupakan 
sumber chitin-chitosan. Nurjanah et al. (2014) juga menyatakan cangkang juga dapat digunakan untuk filtrasi air dan juga sebagai hiasan yang bernilai ekonomis tinggi.

Tabel 2. Rendemen kerang tahu, kerang salju dan keong macan

\begin{tabular}{lccc}
\hline Rendemen & $\begin{array}{c}\text { Kerang } \\
\text { Tahu }(\%)\end{array}$ & $\begin{array}{c}\text { Kerang Salju } \\
(\%)\end{array}$ & $\begin{array}{c}\text { Keong } \\
\text { Macan }(\%)\end{array}$ \\
\hline Daging & $14,38 \pm 0,24$ & $15,48 \pm 0,76$ & $21,81 \pm 0,11$ \\
Jeroan & $18,18 \pm 0,11$ & $23,88 \pm 0,85$ & $11,16 \pm 0,15$ \\
Cangkang & $67,44 \pm 0,56$ & $60,64 \pm 0,15$ & $67,03 \pm 0,2$ \\
\hline
\end{tabular}

Komposisi kimia daging kerang tahu, kerang salju dan keong macan dapat dilihat pada Tabel 3. Air merupakan komponen yang penting dalam bahan makanan, karena air dapat memberikan pengaruh pada penampakan, tekstur serta cita rasa. Bahkan di dalam makanan kering sekalipun, terkandung air dalam jumlah tertentu. Persentase kadar air daging kerang salju lebih tinggi yaitu $83,79 \%$ dibandingkan dengan kerang tahu dan keong macan adalah 79,98 dan $78,44 \%$. Menurut Nurjanah et al. (2014), kadar air pada kupang merah berkisar 82,0-87,0\%. Kadar air kerang salju lebih besar karena kerang salju memiliki ukuran dan berat tubuh yang besar daripada kerang tahu dan keong macan.

Tabel 3. Komposisi kimia daging kerang tahu, kerang salju dan keong macan

\begin{tabular}{lccc}
\hline Jenis Gizi & $\begin{array}{c}\text { Daging } \\
\text { Kerang } \\
\text { Tahu } \\
(\%)(b b)\end{array}$ & $\begin{array}{c}\text { Daging } \\
\text { Kerang } \\
\text { Salju } \\
(\%)(b b)\end{array}$ & $\begin{array}{l}\text { Daging } \\
\text { Keong } \\
\text { Macan } \\
(\%)(b b)\end{array}$ \\
\hline Air & $79,98 \pm 0,15$ & $83,78 \pm 0,11$ & $78,44 \pm 0,19$ \\
Abu & $1,37 \pm 0,23$ & $1,19 \pm 0,23$ & $1,20 \pm 0,13$ \\
Lemak & $0,24 \pm 0,21$ & $0,11 \pm 0,45$ & $0,33 \pm 0,15$ \\
Protein & $9,39 \pm 0,27$ & $11,37 \pm 0,13$ & $17,38 \pm 0,18$ \\
Kabohidrat & $9,02 \pm 0,18$ & $3,55 \pm 0,34$ & $2,65 \pm 0,24$ \\
\hline
\end{tabular}

Abu adalah zat anorganik sisa hasil pembakaran suatu bahan organik. Persentase kadar abu pada daging kerang tahu, kerang salju dan keong macan adalah 1,37; 1,19; dan 1,20\%. Menurut Nurjanah et al. (2014), kadar abu beberapa moluska yaitu Mytilus qalloprovinciallis sekitar 0,7-2,0\% dan Ostra edulis sekitar 1,0-1,6\%. Kadar abu ini menjadi indikator utama untuk melihat kandungan mineral yang ada pada ketiga jenis kekerangan ini. Abdullah et al. (2013) menyatakan bahwa jenis kekerangan mempunyai kandungan mineral makro yang sangat berguna bagi kesehatan. Nurilmala et al. (2015) juga menyatakan bahwa kandungan mineral pada bahan baku hasil perairan sangat bergantung pada parameter kandungan abu. Lemak merupakan zat yang penting dan merupakan sumber energi yang lebih efektif bagi tubuh dibandingkan karbohidrat dan protein. Hasil analisis menunjukkan bahwa persentase kadar lemak pada daging keong macan, kerang salju dan kerang tahu adalah 0,33; 0,24; dan 0,11\%. Kadar lemak yang diperoleh cukup rendah. Nurjanah et al. (2015) menyatakan bahwa lemak yang terkandung pada hasil perairan menganndung asam lemak EPA dan DHA yang sangat baik untuk kesehatan. Abdullah et al. (2013) dalam hasil penelitian menyebutkan bahwa kerang bulu mempunyai kandungan omega-3 yang sangat baik.

Protein merupakan suatu zat makanan yang penting bagi tubuh. Daging keong macan memiliki nilai protein tertinggi $17,38 \%$ dibandingkan dengan daging kerang tahu dan kerang salju sebesar 9,39\% dan $11,37 \%$. Tingginya kadar protein pada keong macan menunjukkan peluang pemanfaatan sebagai salah satu sumber protein hewani. Menurut McLachlan dan Lombard (1980), kadar protein pada keong laut lebih rendah daripada keong darat yaitu $8-16 \%$ dan 1,4-8\%. Hasil perhitungan by difference menunjukkan kadar karbohidrat yang terdapat pada daging kerang tahu sebesar 9,02\%, nilai tersebut lebih besar dibandingkan dengan karbohidrat kerang salju dan keong macan sebesar 3,55 dan 2,65\%. Karbohidrat yang ada dalam produk perikanan tidak mengandung serat, kebanyakan dalam bentuk glikogen. Kandungan glikogen yang terkandung pada produk perikanan sebesar $1 \%$ untuk ikan, $1 \%$ untuk krustasea dan 1-8\% untuk kerang-kerangan (Abdullah et al., 2013).

\section{Komposisi asam amino kerang tahu, kerang salju dan keong macan}

Pengujian asam amino pada daging kerang tahu, kerang salju dan keong macan menghasilkan 15 jenis asam amino yang terdiri atas 9 jenis asam amino esensial dan 6 jenis asam amino non esensial. Asam amino esensial yang terdapat pada sampel adalah histidin, arginin, treonin, valin, metionin, isoleusin, leusin, fenilalanin, lisin. Asam amino non esensial yang terdapat pada sampel adalah asam aspartat, asam glutamat, serin, glisin, alanin dan tirosin. Kandungan asam amino esensial pada tiga sampel dapat dilihat pada Gambar 1. Kandungan asam amino esensial yang tertinggi pada daging kerang tahu, kerang salju dan keong macan adalah arginin sebesar 1,12; 0,93; dan $2,50 \%$. Leusin juga ditemukan pada kerang salju sebesar 0,93\%. Arginin sangat dibutuhkan pada tubuh cephalopoda untuk proses metabolism. Arginin merupakan asam amino yang banyak ditemukan pada otot moluska (Krug et al., 2009). Leusin merupakan asam amino yang paling banyak ditemui pada bahan pangan sumber protein. Leusin dan lisin merupakan asam amino esensial yang banyak ditemukan pada moluska laut. Kandungan asam amino non esensial pada tiga sampel yang digunakan dapat dilihat pada Gambar 2. 


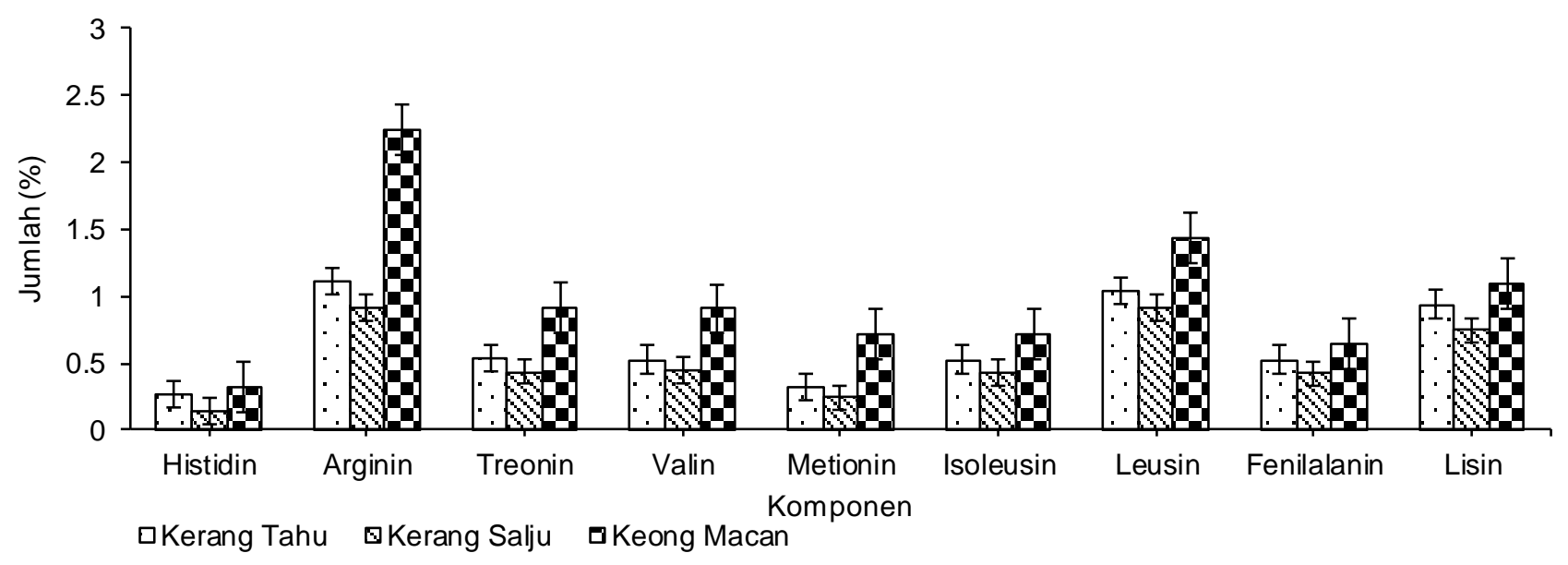

Gambar 1. Kandungan asam amino esensial

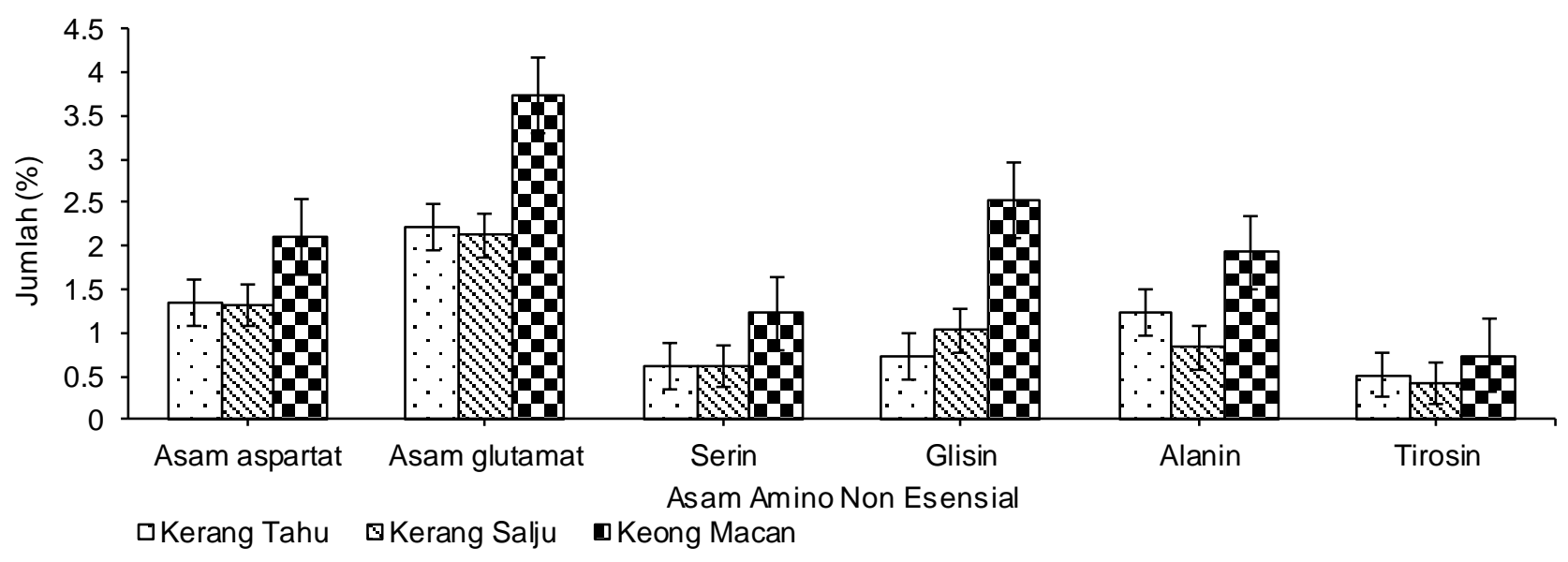

Gambar 2. Kandungan asam amino non esensial

Kandungan asam amino non esensial yang tertinggi pada daging kerang tahu, kerang salju dan keong macan adalah asam glutamat dengan nilai 2,22; 2,07; dan 3,63\%. Asam aspartat dan glisin juga ditemukan cukup tinggi setelah asam glutamat pada kerang tahu, kerang salju dan keong macan. Asam amino non esensial yang banyak ditemui di jaringan otot hewan adalah alanin, glisin, dan asam glutamat (Krug et al., 2009). Asam glutamat mengandung ion glutamat yang dapat merangsang beberapa tipe syaraf yang ada pada lidah manusia. Asam glutamat dan asam aspartat memberikan cita rasa pada seafood, namun dalam bentuk garam sodium yaitu pada MSG akan memberikan rasa umami (Uju et al., 2009). Asam glutamat merupakan komponen paling penting dalam pembentukan cita rasa pada makanan hasil laut. Secara umum, kandungan asam amino yang paling banyak ditemui pada moluska laut adalah asam glutamat, asam aspartat, glisin, alanin dan taurin (Derby et al., 2007). Kadar asam amino yang diperoleh berbedabeda pada kerang tahu, kerang salju dan keong macan. Kandungan asam amino pada masingmasing spesies tidaklah sama, karena masingmasing spesies memiliki proses fisiologis yang berbeda. Perbedaan kandungan asam amino ini juga dapat disebabkan oleh umur, musim penangkapan serta tahapan dalam daur hidup organisme (Abdullah et al., 2013). Taurin merupakan salah satu asam amino bebas yang keberadaannya berlimpah. Taurin merupakan senyawa tidak esensial karena secara internal dapat disintesis dari asam amino metionin atau sistein dan piridoksin (Vitamin B6). Taurin di dalam tubuh berperan dalam pergerakan ion-ion magnesium, kalium, natrium dan kalsium dalam keluar dan masuk sel sehingga membantu koneksi impuls syaraf. Kandungan taurin pada tiga sampel yang digunakan dapat dilihat pada Gambar 3.

Kandungan taurin pada daging kerang salju lebih besar daripada keong macan dan kerang tahu yaitu $0,72 \%$ atau $72 \mathrm{mg} / 100 \mathrm{~g}$. Kandungan taurin daging kerang tahu, kerang salju dan keong macan masih lebih rendah bila dibandingkan dengan beberapa jenis ikan dan golongan moluska yang lain. Kandungan taurin yang terdapat pada cumi-cumi 364 $\mathrm{mg} / 100 \mathrm{~g}$, Short necked clam $421 \mathrm{mg} / 100 \mathrm{~g}$ dan Oyster 1178 mg/100 g (Okuzumi dan Fujii, 2000). Sari et al. (2013) dalam hasil penelitiannya bahwa taurin yang terkandung pada lintah laut dapat 
digunakan sebagai sumber minuman fungsional yang sangat baik untuk kesehatan. Rendahnya kadar taurin pada daging kerang tahu, kerang salju dan keong macan dikarenakan bagian jeroan tidak disertakan dalam analisis taurin pada penelitian ini. Menurut Jiancheng et al. (2010), taurin banyak ditemukan pada jaringan dan dapat disintesis pada jaringan yaitu liver, ginjal, sistem saraf pusat dan retina mata. Selain itu, taurin juga dapat disintesis dari organ reproduksi.

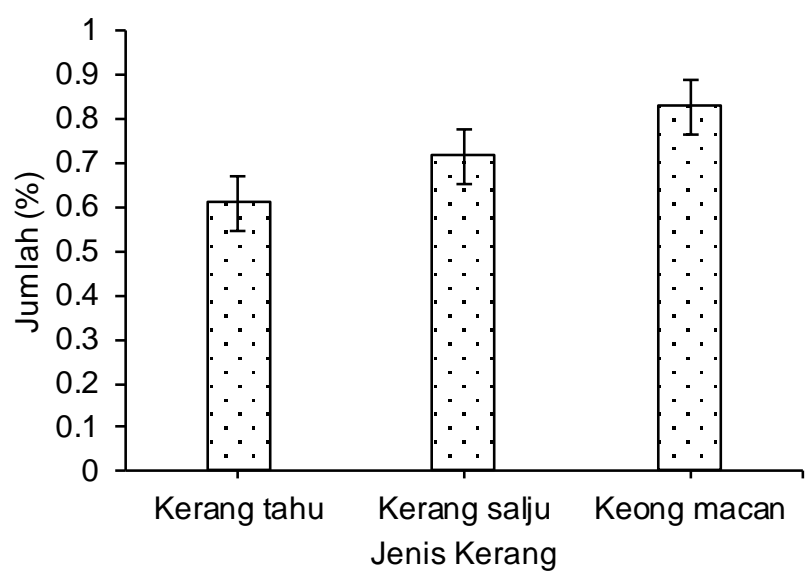

Gambar 3. Kandungan taurine

\section{KESIMPULAN}

Kerang tahu, kerang salju dan keong macan mengandung 15 asam amino yang terdiri atas 9 asam amino esensial dan 6 asam amino non esensial. Asam amino esensial yang terdapat pada kerang tahu, kerang salju dan keong macan adalah histidin, arginin, treonin, valin, metionin, isoleusin, leusin, fenilalanin, lisin. Asam amino non esensial yang terdapat pada sampel adalah asam aspartat, asam glutamat, serin, glisin, alanin dan tirosin. Kandungan asam amino esensial yang tertinggi pada daging kerang tahu, kerang salju dan keong macan adalah arginin. Kandungan asam amino non esensial yang tertinggi pada daging kerang tahu, kerang salju dan keong macan adalah asam glutamat. Kandungan taurin pada daging kerang salju lebih besar daripada keong macan dan kerang tahu.

\section{DAFTAR PUSTAKA}

[AOAC] Association of Official Analytical Chemist. 2007. Official Methods of Analysis of Official Analytical of Chemist. Airlington: The Association of Official Analytical Chemists. $18^{\text {th }}$ edn. Washington DC.

Abdullah A, Nurjanah, Hidayat T, Yusevi V. 2013. Profil asam amino dan asam lemak kerang bulu
(Anadara antiquata). J Pengolahan Hasil Perikanan Indonesia 16: 155-162.

Abdullah A, Nurjanah, Hidayat T, Gifari A. 2016. Caharacterize fatty acids of Babylonia spirata, Meretrix meretrix, Pholas dactylus. Int Chem Biomoleculer Sci 2: 38-42

Derby CD, Kicklighter CE, Jhonson PM, Zang $X$ 2007. Chemical composition of inks of diverse marine molluscs suggests convergent chemical defenses. J Chem 33: 1105-1113. DOI: 10.10 07/s10886-007-9279-0.

Jiancheng Y, Gaofeng W, Ying F, Qiufeng L, Shumel L, Jianmin H. 2010. Effect of taurine on male reproduction in rats of different ages. J Biomed Sci 17: 1-8. DOI: 10.1186/1423-012717-S1-S9.

Krug PJ, Riffell JA, Zimmer RK. 2009. Endogeneos signaling pathway dan chemical communication between sperm and egg. J Exp Biol 212: 10921100. DOI: $10.1242 /$ jeb.027029.

McLachlan A, Lombard HW. 1980. Seasonal variations in energy and biochemical components of an edible gastropod, Turbo sarmaticus (Turbinidae). Aquaculture 19: 117-125.

Nurjanah, Suseno SH, Hidayat T, Pramudhita PS, Ekawati Y, Arifianto TB. 2015. Changes in nutritional composition of skipjack (Katsuwonuspelamis) due to frying process. Int Food Res J 22: 2093-2102.

Nurjanah, Jacoeb AM, Ulma RN, Puspitasari S, Hidayat T. 2014. Komposisi kimia kupang merah (Musculista senhausia) segar dan rebus. J Depik 3: 241-249. DOI: 10.13170/depik.3.3. 2151.

Nurilmala M, Nurjanah, Febriansyah R, Hidayat $T$. 2015. Perubahan kandungan vitamin dan mineral ikan kembung lelaki akibat proses penggorengan. J Depik 4: 115-122. DOI: 10.13170/depik.4.2.2688.

Okuzumi M, Fujii T. 2000. Nutritional and Functional Properties of Squid and Cuttlefish. Japan: National Cooperative Association of Squid Processors. p 223. Jepang.

Sari RM, Nurjanah, Tarman K. 2013. Synergistic of taurine sea slug (Discodoris sp.) and ginger (Curcuma xanthorriza Roxb.) in functional beverage powders. J Pengolahan Hasil Perikanan Indonesia 16: 48-57.

Suptijah P, Nurjanah, Yanuarizki O. 2013. Aktivitas antioksidan dan komponen bioaktif kerang simping. J Pengolahan Hasil Perikanan Indonesia 16: 242-248

Uju, Nurhayati T, Ibrahim B, Trilaksani W, Siburian M. 2009. Karakterisasi dan recovery protein dari air cucian minced fish dengan membran reverse osmosis. J Pengolahan Hasil Perikanan Indonesia 12: 115-127. 
